\title{
Hubungan Peran Keluarga dan Kontrol Diri dengan Perilaku Membolos Siswa
}

\author{
Rini \\ Universitas Negeri Semarang, Semarang, Indonesia \\ rinibk.2@gmail.com \\ Muslikah \\ Universitas Negeri Semarang, Semarang, Indonesia \\ muslikah@mail.unnes.ac.id
}

\begin{abstract}
Abstrak
Penelitian ini bertujuan untuk mengetahui hubungan antara peran keluarga dan kontrol diri dengan perilaku membolos siswa. Metode yang digunakan adalah kuantitatif, dengan sampel sejumlah 111 siswa kelas X dan XI. Pengambilan sampel dalam penelitian ini menggunakan teknik purposive sampling dan teknik analisis data yaitu regresi berganda. Hasil uji data pada penelitian ini didapatkan p-value sebesar 0,016 dengan signifikansi 0,016<0,05 menunjukkan bahwa adanya hubungan antara peran keluarga dan kontrol diri dengan perilaku membolos. Selanjutnya diperoleh hasil koefisien determinasi sebesar 0,271 , yang menunjukkan bahwa variabel bebas yaitu peran keluarga dan kontrol diri memiliki hubungan sebesar 27\% dengan perilaku membolos. Dari hasil tersebut konselor sekolah dapat memberikan layanan bimbingan dan konseling di bidang pribadi maupun sosial yang dapat diterapkan baik dengan layanan klasikal, bimbingan kelompok atau konseling kelompok. Serta meningkatkan kerjasama dengan pihak keluarga untuk mengoptimalkan perkembangan peserta didik.
\end{abstract}

Kata kunci: Perilaku Membolos; Kontrol Diri; Peran Keluarga.

\begin{abstract}
This study is to determine the relationship between the role of family and self-control with truant behavior of students. The method used is quantitative, with a sample of 111 students in class $X$ and XI. Sampling in this study using purposive sampling techniques and data analysis techniques, namely multiple regression. The test results of
\end{abstract}


the data in this study obtained a p-value of 0.016 with a significance of $0.016<0.05$ indicating that there is a relationship between the role of family and self-control with truant behavior. Furthermore, the results obtained by the coefficient of determination of 0.271 , which shows that the independent variable is the role of family and selfcontrol has a relationship of $27 \%$ with truant behavior. From these results school counselors can provide guidance and counseling services in the private and social fields that can be applied either with classical services, group guidance or group counseling. And increase cooperation with the family to optimize the development of students.

Keywords: Truant Behavior; Self Control; Family Role.

\section{A. Pendahuluan}

Remaja merupakan satu identitas yang potensial sebagai penerus cita-cita perjuangan bangsa dan sumber insani bagi pembangunan bangsanya. Hal tersebut menjadi suatu penguatan bagi remaja untuk menjadi pribadi yang dapat mengembangkan segala potensi yang ada pada dirinya sesuai dengan tahap perkembangannya sehingga dapat mengoptimalkan potensi di lingkungan sekitarnya. Akan tetapi pada kenyataannya masih terdapat remaja justru berbuat bertolak belakang dengan pernyataan tersebut. Remaja terjebak dengan kondisi lingkungan yang dapat menyebabkan remaja tersebut untuk berperilaku menyimpang. Perilaku menyimpang merupakan suatu bentuk perilaku negatif yang melanggar norma-norma yang berlaku pada masyarakat atau lingkungan tertentu. Salah satu bentuk perilaku menyimpang tersebut yaitu perilaku membolos. Perilaku membolos merupakan suatu bentuk perilaku siswa yang melanggar peraturan di sekolah. Membolos merupakan suatu bentuk perilaku yang dapat memberikan dampak buruk bagi seorang individu.

Menurut Prayitno dan Erman Amti (2015: 62), perilaku membolos memiliki beberapa dampak seperti minat terhadap pelajaran akan semakin berkurang, gagal dalam ujian, hasil belajar yang diperoleh tidak sesuai dengan potensi

yang dimiliki, tidak naik kelas, penguasaan terhadap materi pelajaran 
tertinggal dari teman-temannya, dan dikeluarkan dari sekolah. Perilaku membolos tersebut tidak hanya berdampak pada diri individu melainkan juga memberikan dampak pada pihak sekolah, dampak dari perilaku membolos dapat menurunkan hasil prestasi siswa dimana kualitas sekolah dapat diperoleh dari hasil prestasi siswa tersebut. Semakin tinggi pencapaian hasil prestasi siswa maka kualitas sekolah semakin tinggi pula. Bentuk dari perilaku membolos tersebut seperti meninggalkan jam pelajaran atau tidak masuk sekolah tanpa keterangan yang jelas dikarenakan oleh beberapa faktor baik dari dalam diri maupun dari luar diri individu. Salah satu faktor dari luar individu tersebut yaitu peran keluarga. Peran keluarga sangat dibutuhkan dalam tumbuh kembang seorang individu, dimana pendidikan yang utama diperoleh individu dari keluarga. Keluarga merupakan tempat pertama seorang individu memperoleh suatu pendidikan baik pendidikan nilai, norma, maupun pendidikan spiritual.

Peran keluarga sangat diperlukan oleh seorang individu di masa remaja, dimana masa tersebut merupakan masa yang rentan untuk mudah terpengaruh dengan kehidupan diluar keluarganya. Oleh karena itu diperlukan perhatian dari keluarga atas apa yang telah dicapai anak agar dirinya merasa diperhatikan dan diperlukan adanya pengawasan dari keluarga terhadap perkembangan anak. Menurut Sari (2016) dalam penelitiannya menunjukkan adanya hubungan antara peran keluarga dengan kecenderungan perilaku delinkuen, yang artinya keluarga dengan suasana penuh kasih sayang, ramah dan bersahabat amat mendukung pertumbuhan anak dan remaja menjadi manusia yang bertanggung jawab.Semakin besar dukungan orang tua, semakin besar harga diri dan perilaku bermoral dalam diri anak. Anak merasa bahwa dirinya dihargai dan diperhatikan oleh orang tua sehingga orang tua menjadi tempat ternyaman untuk menyampaikan segala keinginan dan permasalahan yang sedang dihadapinya. Hal tersebut membantu seorang anak untuk dapat 
mengembangkan segala potensi yang ada pada dirinya. Selain dari faktor keluarga, faktor dalam diri sendiri juga sangat berpengaruh terhadap perilaku membolos yang dilakukian oleh seorang individu.

Faktor dari dalam diri tersebut salah satunya yaitu kontrol diri. Menurut Ghufron dan Risnawati (2014: 21) kontrol diri merupakan suatu kecakapan individu dalam kepekaan membaca situasi diri dan lingkungannya. Seorang individu apabila memiliki kontrol diri yang kurang akan dapat mendorong dirinya untuk melakukan beberapa perilaku yang menyimpang salah satunya yaitu perilaku membolos. Kontrol diri juga dapat diartikan sebagai suatu kemampuan individu untuk dapat mengontrol atau menahan dirinya sendiri untuk tidak melakukan sesuatu secara terburu-buru, yaitu dengan melakukan beberapa pertimbangan-pertimbangan sebelum mengambil keputusan ataupun dalam melakukan sesuatu. ketika seorang individu memiliki kontrol diri yang rendah akan memiliki dorongan yang lebih besar untuk melakukan beberapa perilaku tanpa memperhatikan dampak yang akan diperolehnya.

Pentingnya penelitian ini dilakukan yaitu sebagai seseorang yang berprofesi dalam bidang bimbingan dan konseling harus dapat memahami peserta karakter dan perilakunya dengan baik, salah satunya yaitu perilaku membolos. Perilaku menyimpang yang kerap dilakukan oleh para remaja sehingga dapat dijadikan pemahaman bagi konselor dalam membantu pelaksanaan layanan bimbingan dan konseling. Oleh karena itu peneliti tertarik untuk meneliti hubungan peran keluarga dan kontrol diri dengan perilaku membolos pada peserta didik sehingga penelitian dapat memberikan kontribusi baik bagi pihak pendidikan maupunb keluarga serta pihak-pihak yang terkait dengan peserta didik untuk dapat membantu meminimalkan perilaku membolos.

\section{B. Pembahasan}

\section{Perilaku Membolos}


Perilaku dapat dikatakan sebagai suatu reaksi dari individu, pemunculan perilaku dapat berupa perilaku positif maupun perilaku negatif. Menurut Kurt lewin dalam Arianti (2017) perilaku merupakan fungsi karakteristik individu dan lingkungan yaitu, karakteristik individu meliputi berbagai variabel seperti motif, nilai-nilai, sifat kepribadian, dan sikap yang saling berinteraksi satu sama lain dan kemudian berinteraksi pula dengan faktor-faktor lingkungan dalam menentukan perilaku.

\section{a. Definisi Perilaku Membolos}

Menurut Arianti (2017) perilaku membolos merupakan suatu tindakan atau perilaku siswa yang tidak masuk sekolah dengan alasan yang tidak jelas, atau bisa diartikan ketidakhadiran dengan alasan tidak jelas, serta peserta didikmeninggalkan jam-jam pelajaran tertentu tanpa izin dari pihak guru ataupun pihak sekolah yang bersangkutan. Menurut Reid Ken (1999) menjelaskan bahwa penyebab spesifik pembolosan bervariasi dari survei ke survei dan wilayah ke wilayah, tetapi alasan utama mengapa anak bolos adalah karena mereka tidak suka sekolah. Ketidaksukaan siswa dapat berupa tidak suka terhadap mata pelajaran atau guru yang mengajar tentang mata pelajaran tertentu. Berdasarkan pendapat diatas maka dapat disimpulkan bahwa perilaku membolos merupakan suatu bentuk perilaku siswa yang melanggar peraturan seperti meninggalkan jam pelajaran atau tidak masuk sekolah tanpa keterangan yang jelas dikarenakan oleh beberapa faktor baik dari dalam diri maupun luar diri individu.

\section{b. Aspek-Aspek Perilaku Membolos}

Perilaku membolos adalah salah satu bentuk perilaku pelanggaran yang dilakukan oleh beberapa siswa di sekolah. Aspek perilaku membolos menurut Prayitno dan Erman Amti (2015: 61) tersebut antara lain:

(1) Berhari-hari tidak masuk sekolah; (2) Tidak masuk sekolah tanpa izin;

(3) Sering keluar pada jam pelajaran tertentu; (4) Masuk sekolah berganti 
hari; (5) Mengajak teman-teman untuk keluar pada jam pelajaran yang tidak disenangi; (6) Tidak masuk kelas lagi setelah jam istirahat.

Beberapa aspek tersebut dapat diamati secara langsung oleh guru, akan tetapi ada beberapa siswa yang dapat melakukan perilaku tersebut tanpa sepengetahuan guru maupun staf dari pihak sekolah.

\section{c. Dampak Perilaku Membolos}

Pembolosan berdampak negatif pada siswa dalam beberapa cara. Siswa yang membolos lebih cenderung tertinggal secara akademis, putus sekolah, menggunakan narkoba dan alkohol, dan terlibat dengan sistem peradilan pidana (Smink \& Heilbrunn, 2015) dalam Bye Lynn, etc (2010). Perilaku membolos memberikan beberapa dampak yang kurang baik terhadap individu, salah satunya yang paling merugikan yaitu penurunan prestasi akademik dari siswa karena dalam hal ini perilaku membolos menuntut siswa untuk meninggalkan jam pelajaran sekolah. dan hal tersebut sering kali membuat siswa tertinggal dengan materi pelajaran yang telah disampaikan oleh guru sehingga menyebabkan menurunnya prestasi hasil belajar siswa.

Menurut Prayitno dan Erman Amti (2015: 62), perilaku membolos memiliki beberapa dampak, antara lain:

1. Minat terhadap pelajaran akan semakin kurang

2. Gagal dalam ujian

3. Hasil belajar yang diperoleh tidak sesuai dengan potensi yang dimiliki

4. Tidak naik kelas

5. Penguasaan terhadap materi pelajaran tertinggal dari temanteman lainnya

6. Dikeluarkan dari sekolah.

Dampak yang ditimbulkan dari perilaku membolos tersebut memberikan pengaruh pula terhadap hasil belajar siswa di sekolah. Hal 
tersebut juga akan menimbulkan ketidakpuasan orang tua terhadap hasil belajar yang dicapai oleh seorang anak di dalam sekolahnya.

Dapat disimpulkan bahwa dampak dari perilaku membolos tidak hanya terhadap diri sendiri seperti berkurangnya minat untuk belajar kemudian prestasi hasil belajar yang menurun akan tetapi juga memberikan dampak ada pihak diluar diri individu seperti dampak terhadap pihak sekolah dan masyarakat.

\section{Peran Keluarga}

\section{a. Definisi Peran Keluarga}

Menurut Nikmah (2016) peranan adalah tindakan atau aktivitas atau serangkaian tingkah laku yang berhubungan dengan norma-norma, peraturan-peraturan dalam melaksanakan kewajiban sesuai dengan situasi dan kondisi serta posisi seseorang dalam suatu tatanan kehidupan untuk mencapai tujuan yang diinginkan. Disisi lain peranan ini juga menuntut kesadaran seseorang bertanggung jawab di masyarakat untuk memberikan pengaruh membimbing dalam upaya memberikan motivasi untuk mewujudkan tujuan yang dicapai. Keluarga merupakan lingkungan pertama dimana anak hidup dan mendapatkan pendidikan dalam rumah tangga, di sinilah tempat anak belajar tentang kebiasaannya dalam mengenal banyak hal, dalam kondisi baik, anak akan mendapat pengaruh kebaikannya dan jika tidak, anak akan tenggelam dalam kesukarannya. Keluarga berfungsi sebagai sarana mendidik, mengasuh, dan mensosialisasikan anak, mengembangkan kemampuan seluruh anggotanya agar dapat menjalankan fungsinya di masyarakat dengan baik, serta memberikan kepuasan dan lingkungan yang sehat guna tercapainya keluarga sejahtera (Asep, 2010: 91). Dapat disimpulkan bahwa peran keluarga merupakan keterlibatan keluarga dalam memberikan perhatian atau perlakuan guna membimbing 
anak meningkatkan kemampuan dalam dirinya untuk mencapai masa depan.

\section{b. Aspek Peranan Keluarga}

Menurut Covey dalam Yusuf (2009: 47) mengajukan empat prinsip peranan keluarga, yaitu:

1. Modelling (example of trustworthness). Orangtua adalah contoh atau model bagi anak. Tidak dapat disangkal bahwa contoh dari orangtua mempunyai engaruh yang sangat kuat bagi anak. Orangtua merupakan model yang pertama dan terdepan bagi anak (baik positif atau negatif) dan merupakan pola bagi "way of life" anak. Cara berfikir dan berbuat anak dibentuk oleh cara berfikir dan berbuat orangtuanya. Melalui "modelling" orangtua telah mewariskan cara berfikirnya kepada anak, yang kadang-kadang sampai pada generasi ketiga atau keempat. Oleh karena itu, maka peranan "modelling” orangtua bagi anak dipandang sebagai suatu hal yang sangat mendasar, suci dan perwujudan spiritual. Melalui "modelling" ini juga anak akan belajar tentang sikap proaktif, sikap respek dan kasih sayang.

2. Mentoring, yaitu kemampuan untuk menjalin atau membangun hubungan, investasi emosional (kasih sayang kepada orang lain) atau pemberian perlindungan kepada orang lain secara mendalam, jujur, pribadi, dan tidak bersyarat. Kedalaman dan kejujuran atau keikhlasan memberikan perlindungan ini akan mendorong orang lain untuk bersikap terbuka dan mau menerima pengajaran, karena dalam diri mereka telah tertanam perasaan percaya. Orangtua menjadi sumber pertama bagi perkembangan perasaan anak: rasa aman atau tidak aman, dicintai atau dibenci. 
3. Organizing, yaitu keluarga seperti perusahaan yang memerlukan tim kerja dan kerjasama antaranggota dalam menyelesaikan tugas-tugas atau memenuh kebutuhan keluarga. Peran organizing adalah untuk meluruskan struktur dan sistem keluarga dalam rangka membantu menyelesaikan hal-hal yang penting.

4. Teaching, orangtua berperan sebagai guru (pengajar) bagi anak-anaknya (anggota keluarga) tentang hukum-hukum dasar kehidupan. Melalui pengajaran ini, orangtua berusaha memberdayakan (empowering) prinsip-prinsip kehidupan, sehingga anak memahami dan melaksanakannya. Peran orangtua sebagai guru adalah menciptakan “conscious competence” pada diri anak, yaitu mereka mengalami tentang apa yang mereka kerjakan dan alasan tentang mengapa mereka mengerjakan itu.

\section{Kontrol Diri}

\section{a. Definisi Kontrol Diri}

Ghufron dan Risnawati (2014: 21) mengungkapkan kontrol diri merupakan suatu kecakapan individu dalam kepekaan membaca situasi diri dan lingkungannya. Selai itu, juga kemampuan untuk mengontrol ddan mengelola faktor-faktor perilaku sesuai dengan situasi dan kondisi untuk menampilkan diri dalam dalam melakukan sosialisasi kemampuan untuk mengendalikan perilaku, kecenderungan menarik perhatian, keinginan mengubah perilaku agar sesuai untuk orang lain, menyenangkan orang lain, selalu konfirm dengann orang lain, dan menutupi perasaannya.

\section{b. Aspek Kontrol Diri}

Kontrol diri mempunyai beberapa jenis. Menurut Ghufron dan Risnawati (2014: 29), kontrol diri dibagi menjadi tiga jenis yaitu kontrol perilaku (behavior control), kontrol kognitif (cognitive control), dan mengontrol keputusan (decision control). Ghufron dan Risnawati (2014: 31) 
menyatakan untuk mengukur kontrol diri biasanya digunakan aspek-aspek seperti :1) kemampuan mengontrol perilaku, 2) kemampuan mengontrol stimulus , 3) kemampuan mengantisipasi suatu peristiwa atau kejadian, 4) kemampuan menafsirkan peristiwa atau kejadian, 5) kemampuan mengambil keputusan.

\section{c. Faktor yang Mempengaruhi Kontrol Diri}

Faktor-faktor yang turut mempengaruhi kontrol diri seseorang biasanya disebabkan oleh banyak faktor. Namun pada dasarnya, kontrol diri itu secara garis besar dipengaruhi oleh faktor eksternal dan internal. Faktor internal, meliputi: faktor hirarki dasar biologi yang telah terorganisasi dan tersusun melalui pengalaman evolusi dan kontrol emosi yang sehat diperoleh bila seorang remaja memiliki kekuatan ego, yaitu suatu kemampuan untuk menahan diri dan tindakan luapan emosi. Sedangkan, faktor eksternal dipengaruhi oleh kondisi sosio-emosional lingkungan, terutama lingkungan keluarga dan kelompok teman sebaya.

Lingkungan keluarga sangat berperan dalam mempengaruhi kontrol diri seorang anak. Orang tua dalam keluarga dijadikan sebagai model oleh anak, anak akan meniru apabila orang tua tidak dapat mengendalikan dirinya sendiri. Oleh karena itu dalam hal ini orang tua perlu menigkatkan dalam kontrol diri sebagai contoh bagi sang anak dalam pembentukan karakter pribadi anak.

Dapat disimpulkan bahwa kontrol diri seseorang dapat disebabkan oleh faktor internal dan faktor eksternal, dimana faktor internal merupakan faktor yang berasal dari dalam diri individu tersebut sedangkan faktor eksternal merupakan faktor yang berasal dari luar diri individu yaitu baik dari lingkungan masyarakat sekitar maupun lingkungan sekolah. 


\section{Metode Penelitian}

Penelitian ini menggunakan desain penelitian korelasional untuk mengukur variabel peran keluarga, kontrol diri, dan perilaku membolos. Penelitian ini dilaksanakan di SMK Tunggal Cipta Manisrenggo Klaten pada kelas X dan XI dengan jumlah sampel 111 siswa dengan menyebarkan angket perilaku membolos dan skala psikologis tentang peran keluarga dan control diri. Pada penelitian ini teknik sampling yang digunakan adalah purposive sampling yaitu teknik penentuan sampel dengan pertimbangan tertentu (2016: 124). Dalam penelitian ini sampel yang diambil adalah siswa kelas X dan XI SMK Tunggal Cipta Manisrenggo Klaten yang pernah melakukan perilaku membolos dengan kriteria sebagai berikut:

1. Siswa tidak masuk sekolah tanpa alasan yang jelas.

2. Masuk sekolah tetapi meninggalkan kelas pada saat jam pelajaran tertentu.

3. Siswa berangkat dari rumah tetapi tidak sampai di sekolah.

4. Tidak masuk sekolah tanpa alasan yang jelas minimal 3 kali dalam sebulan sesuai dengan rekap kehadiran siswa.

Analisis data dengan menggunakan analisis regresi. Menurt Sugiyono (2016: 215) Analisis regresi digunakan untuk melakukan prediksi, bagaimana perubahan nilai variabel dependen bila nilai variabel independen dinaikkan atau diturunkan nilainya.

\section{Hasil Penelitian dan Pembahasan}

\section{a. Hasil Penelitian}

Dari penelitian yang telah dilakukan oleh peneliti dimana peneliti memiliki 3 (tiga) variabel yang telah diolah menggunakan bantuan IBM SPSS 23 maka diperoleh hasil sebagai berikut:

Tabel 1 Tingkat Perilaku Membolos

\begin{tabular}{lllll}
\hline No. & Interval Skor & F & Persentase & Kriteria \\
\hline
\end{tabular}




\begin{tabular}{ccccc}
\hline 1. & $123-145$ & 4 & $3 \%$ & Sangat tinggi \\
\hline 2 & $100-122$ & 28 & $7 \%$ & Tinggi \\
\hline 3 & $77-99$ & 68 & $61 \%$ & Sedang \\
\hline 4 & $54-76$ & 28 & $25 \%$ & Rendah \\
\hline 5 & $30-53$ & 3 & $4 \%$ & Sangat rendah \\
\hline & Jumlah & 111 & $100 \%$ & \\
\hline & & $\begin{array}{c}\text { Rata-rata } \\
\text { Kriteria }\end{array}$ & Sedang \\
\hline
\end{tabular}

Berdasarkan tabel 1 perilaku membolos dapat diketahui bahwa siswa di SMK Tunggal Cipta termasuk dalam kategori sedang. Hal tersebut dapat dilihat dari hasil penghitungan persentase sebanyak 61\% yang terdiri dari 68 siswa dari 111 siswa memiliki perilaku membolos yang termasuk dalam kategori sedang 28 siswa yang termasuk kategori rendah dengan persentase 25\%, kemudian terdapat 8 siswa yang termasuk dalam kategori tinggi dengan persentase $7 \%$, selanjutnya 4 siswa dalam kategori sangat tinggi dengan persentase $4 \%$, dan 3 siswa dalam kategori sangat rendah dengan persentase $3 \%$.

Sedangkan, deskripsi data perilaku membolos per indikator yaitu berharihari tidak masuk sekolah, tidak masuk sekolah tanpa izin, sering keluar pada jam pelajaran, masuk sekolah berganti hari, mengajak teman-teman untuk keluar pada jam pelajaran yang tidak disenangi, tidak masuk kelas lagi setelah jam istirahat dapat dilihat pada tabel 2

Tabel 2 Tabel Deskripsi Data Peran Keluarga per Indikator

\begin{tabular}{llcc}
\hline No & Indikator & Persentase & Kriteria \\
\hline 1. & $\begin{array}{l}\text { Berhari-hari tidak } \\
\text { masuk sekolah }\end{array}$ & $64,3 \%$ & Sedang \\
\hline 2. & $\begin{array}{l}\text { Tidak masuk } \\
\text { sekolah tanpa izin }\end{array}$ & $62,2 \%$ & Sedang \\
\hline 3. & $\begin{array}{l}\text { Sering keluar } \\
\text { pada jam } \\
\text { pelajaran }\end{array}$ & $64,1 \%$ & Sedang \\
\hline 4. & $\begin{array}{l}\text { Masuk sekolah } \\
\text { berganti hari }\end{array}$ & $62,8 \%$ & Sedang \\
\hline 5. & $\begin{array}{l}\text { Mengajak teman- } \\
\text { teman }\end{array}$ & $68,5 \%$ & Tinggi \\
\hline
\end{tabular}




\begin{tabular}{llll} 
& keluar pada jam & & \\
pelajaran yang & & \\
tidak disenangi & & Sedang \\
\hline $6 . \quad \begin{array}{l}\text { Tidak masuk kelas } \\
\text { lagi setelah jam } \\
\text { istirahat }\end{array}$ & & \\
\hline
\end{tabular}

Berdasarkan tabel 2 diketahui bahwa indikator berhari-hari tidak masuk sekolah sebesar 64,3\% dalam kategori sedang, indikator tidak masuk sekolah tanpa izin sebesar $62,2 \%$ dalam kategori sedang, indikator sering keluar pada jam pelajaran sebesar 64,1\% sedang, indikator masuk sekolah berganti hari sebesar 62,8\% dalam kategori sedang, indikator mengajak teman-teman untuk keluar pada jam pelajaran yang tidak disenangi sebesar 68,5\% dalam kategori tinggi, dan indikator tidak masuk kelas lagi setelah jam istirahat sebesar 63,17\% dalam kategori sedang. Sehingga indikator tertinggi dari perilaku membolos pada siswa SMK Tunggal Cipta Manisrenggo Klaten yaitu mengajak teman-teman untuk keluar pada jam pelajaran yang tidak disenangi sebesar $68,5 \%$.

Sedangkan untuk menghitung ada tidaknya hubungan peran keluarga dan kontrol diri dengan perilaku membolos menggunakan penghitungan regresi berganda ditemukan hasil pada tabel 3 sebagai berikut:

Tabel 3 Hasil Uji Regresi Linier Berganda Antara Peran Keluarga dan Kontrol Diri dengan Perilaku Membolos pada Siswa SMK Tunggal Cipta Manisrenggo Klaten

\begin{tabular}{lcccccc}
\hline \multicolumn{1}{c}{ Variabel } & $\mathbf{R}$ & $\mathbf{R}^{\mathbf{2}}$ & $\mathbf{F}$ & $\mathbf{B}$ & $\mathbf{T}$ & Sig \\
\hline $\begin{array}{l}\text { Peran Keluarga, Kontrol Diri } \\
\text { dan Perilaku Membolos }\end{array}$ & 0,271 & 0,073 & 4,265 & - & - & 0,016 \\
\hline
\end{tabular}

Berdasarkan tabel 3 Dengan melihat tabel output SPSS di atas, diperoleh p-value sebesar 0,016, dengan nilai sig. 0,016 < 0,05 Dengan kata lain hasil tersebut menunjukkan bahwa variabel peran keluarga ( $\left.\mathrm{X}_{1}\right)$ dan kontrol diri $\left(\mathrm{X}_{2}\right)$ secara bersama-sama memiliki hubungan dengan variabel 
perilaku membolos (Y). Hal ini berarti hipotesis yang berbunyi "ada hubungan antara peran keluarga dan kontrol diri dengan perilaku membolos" dapat diterima.

Selanjutnya untuk mengetahui besar hubungan antara peran keluarga dan kontrol diri dengan perilaku membolos dapat dilihat dari tabel 4.14 bahwa koefisien determinasi sebesar 0,271. Dengan nilai koefisien determinasi 0,271 dapat disimpulkan bahwa variabel bebas dari penelitian yaitu peran keluarga dan kontrol diri memiliki hubungan sebesar $27 \%$ dengan perilaku membolos.

\section{b. Pembahasan}

Hasil analisis deskriptif varibel perilaku membolos pada siswa SMK Tunggal Cipta menunjukkan dalam kategori sedang. Berdasarkan hasi deskriptif tiap indikator dapat diketahui bahwa indikator mengajak temanteman untuk keluar pada jam pelajaran yang tidak disenangi menjadi indikator yang dominan dan memiliki persentase paling tinggi diantara indikator dari perilaku membolos yang lainnya. Dalam hal ini bahwa siswa kelas X dan XI SMK Tunggal Cipta masih terdapat siswa yang melakukan perilaku membolos. Tindakan membolos tersebut memiliki dampak yang kurang baik terhadap siswa. Sesuai dengan penelitian yang dilakukan oleh Damayanti (2013) menunjukkan bahwa perilaku membolos dapat mempengaruhi akademik di sekolah, karena tidak dapat menyelesaikan topik mata pelajaran pada hari itu juga.

Berdasarkan hasil yang telah dilakukan menunjukkan bahwa terdapat hubungan yang negatif antara peran keluarga dan kontrol diri dengan perilaku membolos dan dalam hal ini bahwa semakin tinggi peran keluarga dan kontrol diri maka akan semakin rendah tingkat perilaku membolos yang dilakukan oleh peserta didik. Hasil penelitian yang dilakukan oleh Damayanti (2013) menunjukkan bahwa faktor-faktor penyebab dari perilaku membolos yaitu permasalahan yang berasal dari diri sendiri, faktor keluarga, dan faktor 
sekolah, kemudian perilaku membolos dapat mempengaruhi akademik di sekolah karena tidak dapat menyelesaikan topik mata pelajaran pada hari itu juga. Faktor penyebab individu melakukan perilaku membolos diantaranya yaitu faktor internal dan faktor eksternal. Faktor internal salah satunya yaitu kontrol diri, sedangkan faktor eksternal salah satunya yaitu peran keluarga.

Peran keluarga menjadi sesuatu hal yang dibutuhkan oleh seseorang anak dalam masa tumbuh dan kembangnya. Aspek dari peran keluarga diantaranya yaitu modelling, mentoring, organizing, dan teaching. Keluarga harus mampu memberikan contoh perilaku yang baik kepada anak serta memberikan pengetahuan baik dalam aspek kognitif, afektif, dan psikomotoriknya. Efektivitas peran keluarga dalam perkembangan karakter anak dapat menjadi modal awal anak dalam pembentukan karakter anak agar dapat berinteraksi, berkomunikasi dan berperilaku dengan yang lainnya (Hulukati, 2015). Oleh karena itu diperlukan adanya kerjasama yang baik antar anggota keluarga, sehingga anak dapat berkembang secara optimal sesuai dengan kemampuan yang dimilikinya. Hal tersebut menjadi pendukung bahwa peran keluarga yang menjadi faktor dari keluarga yang merupakan salah satu permasalahan dari luar diri individu yang memiliki hubungan dengan perilaku membolos yang dilakukan oleh peserta didik.

Sesuai dengan penelitian yang dilakukan Putri (2017) menunjukkan bahwa terdapat hubungan yang negatif dan signifikan antara kontrol diri dan perilaku membolos siswa, oleh karena itu siswa melakukan perilaku membolos dapat disebabkan karena adanya kontrol diri yang rendah. Hasil penelitian yang telah dilakukan Olivia (2017) menunjukkan bahwa terdapat hubungan antara kontrol diri dengan perilaku membolos siswa. Menurut Goldfried dan Merbaum dalam (Ghufron \& Rini, 2014) mendefinisikan bahwa kontrol diri merupakan suatu kemampuan untuk menyusun, membimbing, mengatur dan mengarahkan perilaku yang dapat membawa individu kearah konsekuensi positif. Dalam hal ini dengan kontrol diri seorang individu dapat 
memposisikan dirinya untuk dapat melakukan suatu perilaku kearah yang positif. Mengontrol diri berarti individu berusaha untuk mengarahkan dirinya terhadap sesuatu yang bermanfaat dan dapat diterima secara sosial.

Siswa dengan kontrol diri yang rendah maka perilaku membolosnya akan tinggi, dan begitu sebaliknya (Olivia, 2017). Siswa melakukan perilaku membolos sering kali tidak memperhatikan dampak dari tindakan yang akan dilakukan, hal tersebut merupakan siswa kurang dapat mengontrol dirinya untuk melakukan suatu perilaku dan dampak yang ditimbulkan dari tindakannya tersebut. Sehingga dapat diartikan apabila siswa mempunyai kontrol diri yang tinggi maka perilaku membolos akan menurun. Begitupun sebaliknya, apabila siswa mempunyai kontrol diri yang rendah maka perilaku membolos akan semakin meningkat. Hasil penelitian ini memperkuat teori yang dikemukakan oleh Kinder et al dalam (Reid, 1999) bahwa salah satu faktor perilaku bolos adalah kurangnya kontrol diri, sehingga membuat siswa membolos sekolah.

Hal ini juga dapat mendukung bahwa kontrol diri menjadi salah satu faktor penyebab dari perilaku membolos siswa sehingga adanya keterkaitan hubungan antara kontrol diri dengan perilaku membolos. Maka diperoleh hasil dalam penelitian yang dilakukan bahwa terdapat hubungan antara peran keluarga dan kontrol diri dengan perilaku membolos siswa. Peran keluarga dan kontrol diri secara bersama-sama berhubungan dengan perilaku membolos, ini artinya bahwa untuk menurunkan tingkat perilaku membolos pada siswa, salah satu upaya yang dapat dilakukan oleh pihak orang tua siswa maupun pihak sekolah yaitu membangun dan meningkatkan peran keluarga dengan memberikan suatu perhatian dan lebih aktif memahami perkembangan anak baik di lingkungan sekolah, keluarga, maupun masyarakat sehingga komunikasi antara anak dan keluarga dapat berjalan dengan baik untuk dapat membantu perkembangan diri siswa secara optimal. Serta pihak sekolah terutama guru BK dapat membantu 
meningkatkan kontrol diri dan menurunkan perilaku membolos yang dilakukan oleh siswa dengan memberikan beberapa layanan dalam bidang bimbingan dan konseling baik dalam bentuk kelompok maupun individu.

\section{Simpulan}

Berdasarkan hasil penelitian yang telah dilakukan oleh peneliti, maka dapat disimpulkan bahwa terdapat hubungan negatif antara peran keluarga dan kontrol diri dengan perilaku membolos. Hal ini memiliki arti bahwa semakin tinggi peran keluarga dan kontrol diri dari seorang siswa atau peserta didik maka akan semakin rendah perilaku membolos. Kemudian penelitian ini memiliki manfaat untuk guru BK atau konselor sekolah untuk meningkatkan layanan dalam bidang bimbingan dan konseling yang berkaitan dengan bidang pribadi serta meningkatkan hubungan dengan pihak keluarga untuk menjalin kerjasama yang baiuk dalam membentuk kepribadian siswa.

\section{DAFTAR PUSTAKA}

Asep, J. (2010). Pendidikan Karakter Teori dan Aplikasi. Direktorat Jendral Manajemen Pendidikan dan Menengah Kementrian Pendidikan Nasional.

Damayanti, F. A. (2013). Studi Tentang Perilaku Membolos Pada Siswa Sma Swasta Di Surabaya. Jurnal BK UNESA, 3(1), Article 1. https://jurnalmahasiswa.unesa.ac.id/index.php/jurnal-bkunesa/article/view/4075

Ghufron, M. N., \& Rini, R. S. (2014). Teori-Teori Psikologi. Ar-Ruz media.

Hulukati, W. (2015). Peran Lingkungan Keluarga Terhadap Perkembangan Anak. MUSAWA, Vol. 7. No. 2, 265-282.

Nikmah. (2016). Peranan Orangtua dalam Membimbing Anak untuk Melaksanakan Sholat Lima Waktu di Lingkungan Pasar Kahayan Palangka Raya (Studi Terhadap Lima Kepala Keluarga yang Berprofesi sebagai Pedagang) [Skripsi]. Institut Agama Islam Negeri Palangka Raya.

Olivia, R. F. (2017). Hubungan Antara Kontrol Diri dengan Perilaku Membolos Siswa Kelas X SMKN 1 Ngasem Kediri Tahun Ajaran 2016/2017 [Skripsi]. Universitas Nusantara PGRI Kediri.

Prayitno, E. A., \& Amti, E. (2015). Dasar-dasar Bimbingan dan Konseling. Rineka Cipta. 
Putri, L. R. (2017). Pengaruh Konformitas Teman Sebaya terhadap. Perilaku Membolos pada Remaja SMKN 10 Semarang [Skripsi]. Universitas Negeri Semarang.

Reid, K. (1999). Truancy and Schools (1 edition). Routledge.

Risky, A. (2017). Faktor-Faktor yang Mempengaruhi Perilaku Membolos Peserta Didik Kelas VIII di Sekolah Menengah Pertama Negeri 13 Bandar Lampung Tahun Ajaran 2016/2017 [Skripsi]. Universitas Islam Negeri Raden Intan.

Sari, N. K. (2016). Hubungan Antara Peran keluarga dengan Kecenderungan Perilaku Delinkuen pada Remaja [Skripsi]. Universitas Muhammadiyah Surakarta.

Sugiyono. (2016). Metode Penelitian Pendidikan Pendekatan Kuantitatif, Kualitatif dan $R \& D$. Alfabeta.

Yusuf, S. (2009). Psikologi Perkembangan Anak dan Remaja. Remaja Rosdakarya Offset. 